\title{
THE
}

\section{Differential Fmo3 gene expression in various liver injury models involving hepatic oxidative stress in mice}

\author{
Swetha Rudraiah \\ Jamie E. Moscovitz \\ Ajay C. Donepudi \\ University of Rhode Island \\ Sarah N. Campion \\ Angela L. Slitt \\ University of Rhode Island, angela_slitt@uri.edu
}

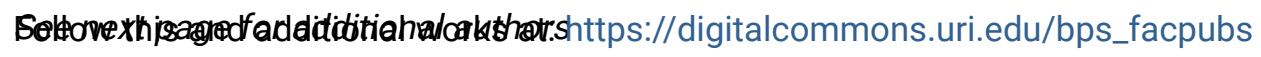

This is a pre-publication author manuscript of the final, published article.

Creative Commons License

(c) $($ ) $(9)$

This work is licensed under a Creative Commons Attribution-Noncommercial-No Derivative Works 4.0 License.

\section{Citation/Publisher Attribution \\ Rudraiah, S., Moscovitz, J. E., Donepudi, A. C., Campion, S. N., Slitt, A. L., Aleksunes, L. M., \& Manautou, J. E. (2014). Differential $F m o 3$ gene expression in various liver injury models involving hepatic oxidative stress in mice. Toxicology, 325, 85-95. doi: 10.1016/j.tox.2014.08.013 \\ Available at: https://doi.org/10.1016/j.tox.2014.08.013}

This Article is brought to you for free and open access by the Biomedical and Pharmaceutical Sciences at DigitalCommons@URI. It has been accepted for inclusion in Biomedical and Pharmaceutical Sciences Faculty Publications by an authorized administrator of DigitalCommons@URI. For more information, please contact digitalcommons-group@uri.edu. 


\section{Authors}

Swetha Rudraiah, Jamie E. Moscovitz, Ajay C. Donepudi, Sarah N. Campion, Angela L. Slitt, Lauren M. Aleksunes, and José E. Manautou 


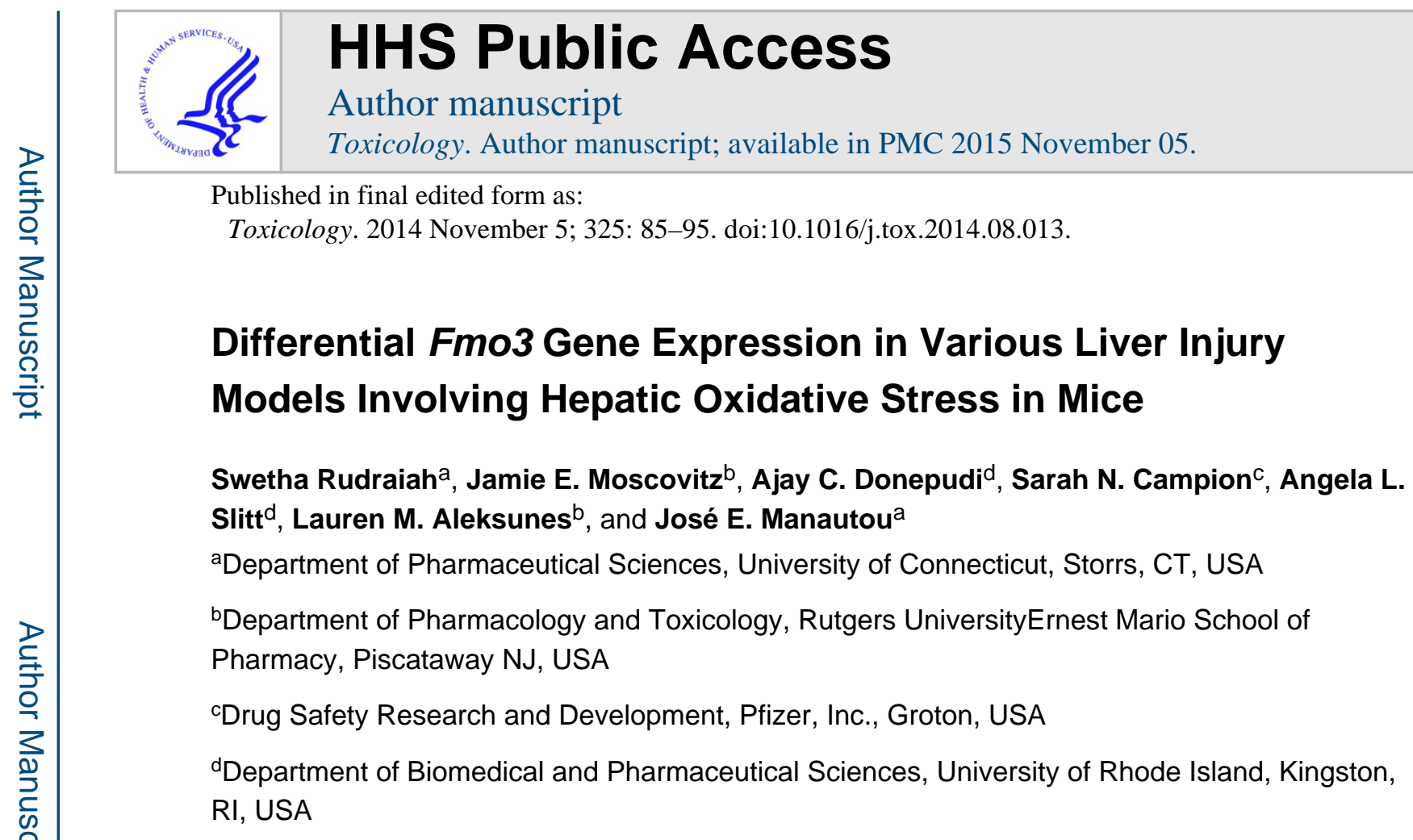

\section{Abstract}

Flavin-containing monooxygenase-3 (FMO3) catalyzes metabolic reactions similar to cytochrome P450 monooxygenase however, most metabolites of FMO3 are considered non-toxic. Recent findings in our laboratory demonstrated Fmo3gene induction following toxic acetaminophen (APAP) treatment in mice.The goal of this study was to evaluate Fmo3gene expression in diverseother mouse models of hepatic oxidative stress and injury. Fmo3 gene regulation by Nrf2 was also investigated using Nrf2 knockout (Nrf2 KO) mice. In our studies, male C57BL/6J mice were treated with toxic dosesof hepatotoxicants or underwent bile duct ligation (BDL, 10d). Hepatotoxicants included APAP (400 mg/kg, 24 to 72h), alpha-naphthylisothiocyanate (ANIT; 50 $\mathrm{mg} / \mathrm{kg}, 2$ to $48 \mathrm{~h}$ ), carbontetrachloride $\left(\mathrm{CCl}_{4} ; 10\right.$ or $30 \mu \mathrm{L} / \mathrm{kg}, 24$ and $48 \mathrm{~h}$ ) and allyl alcohol (AlOH; 30 or $60 \mathrm{mg} / \mathrm{kg}, 6$ and 24h). Because oxidative stress activates nuclear factor (erythroid-derived 2)-like 2 (Nrf2), additional studies investigated $F m o 3$ gene regulation by Nrf2 using Nrf2 knockout (Nrf2 KO) mice. At appropriate time-points, blood and liver samples were collected for assessment of plasma alanine aminotransferase (ALT) activity, plasma and hepatic bile acid levels, as well as liver Fmo3 mRNA and protein expression. Fmo3 mRNA expression increased

() 2014 Elsevier Ireland Ltd. All rights reserved.

Corresponding Author: Dr. José E. Manautou Toxicology Program, Department of Pharmaceutical Sciences, School of Pharmacy, University of Connecticut, 69 North Eagleville Road, Unit 3092, Storrs, CT 06269-3092 Phone: (860) 486-3852 Fax: (860) 486-5792 jose.manautou@uconn.edu. swetha.rudraiah@uconn.edu

jamie.moscovitz@rutgers.edu ajaydonepudi@gmail.com sarah.campion@pfizer.com angela_slitt@ds.uri.edu aleksunes@eohsi.rutgers.edu

Publisher's Disclaimer: This is a PDF file of an unedited manuscript that has been accepted for publication. As a service to our customers we are providing this early version of the manuscript. The manuscript will undergo copyediting, typesetting, and review of the resulting proof before it is published in its final citable form. Please note that during the production process errors may be discovered which could affect the content, and all legal disclaimers that apply to the journal pertain.

Conflict of interest

The authors declare that there are no conflicts of interest. 
significantly by 43 -fold at $12 \mathrm{~h}$ after ANIT treatment,and this increase translates to a 4 -fold change in protein levels. BDL also increased Fmo3 mRNA expression by 1899 -fold, but with no change in protein levels. Treatment of mice with $\mathrm{CCl}_{4}$ decreased liver Fmo3gene expression, whileno change in expression was detected with $\mathrm{AlOH}$ treatment. Nrf2 $\mathrm{KO}$ mice are more susceptible to APAP (400 mg/kg, 72h) treatment compared to their wild-type (WT) counterparts, which is evidenced by greater plasma ALT activity. Fmo3 mRNA and protein expression increased in Nrf2 KO mice after APAP treatment. Collectively, not all hepatotoxicantsthat produce oxidative stress alter Fmo3gene expression. Along with APAP, toxic ANIT treatment in mice markedly increased $F m o 3$ gene expression. While BDL increased Fmo3 mRNA expression, protein level did not change. The discrepancy with Fmo3 induction in cholestatic models, ANIT and BDL, is not entirely clear. Results from Nrf2 KO mice with APAP suggest that the transcriptional regulation of $F m o 3$ during liver injury may not involve Nrf2.

\section{Keywords}

Flavin-containing monoxygenase-3; Hepatotoxicants; Acetaminophen; Alphanaphthylisothiocyanate; Bile duct ligation; Carbon tetrachloride; Allyl alcohol; Oxidative stress; Nrf2

\section{Introduction}

Drug-induced liver injury (DILI) is a significant challenge for both drug development and clinical care. It accounts for more than $50 \%$ of all acute liver failure cases in the U.S. (Larson et al., 2005; W. M. Lee, 2010). Many chemicals, such as acetaminophen (APAP), carbontetrachloride $\left(\mathrm{CCl}_{4}\right)$ and allyl alcohol $(\mathrm{AlOH})$ have been used to model hepatotoxicity relevant to human exposure. Alpha-naphthylisothiocyanate (ANIT) and bile duct ligation (BDL) on the other hand are used to model cholestasis, a pathological condition caused by impairment of hepatic bile flow. While ANIT produces intrahepatic cholestasis, BDL produces extrahepatic cholestasis. With APAP and $\mathrm{CCl}_{4}$, the parent compound is metabolized by cytochrome P450 (CYP) to generate reactive metabolites, N-acetyl-pbenzoquinone imine (NAPQI) and tricholoromethyl radical $\left(\mathrm{CCl}_{3}\right)$, respectively.AlOHin turn is metabolized in the liver by alcohol dehydrogenase to its reactive metabolite, acrolein. The glutathione adductof acrolein is converted by CYPs to glycidaldehyde. Toxicity resulting from these reactive metabolites is multifactorial and includes lipid peroxidation, generation of oxidative stress, altered cellular redox status and protein adduct formation(Burcham \& Fontaine, 2001; Cohen et al., 1997; Jaeschke et al., 2012; Ohno et al., 1985; Tom et al., 1984). During cholestasis resulting from either BDL or ANIT treatment, increase in bile acid concentration stimulates production of reactive oxygen species eventually leading to hepatocellular necrosis and apoptosis (Sokol et al., 1995; Trauner et al., 1998).

The role of nuclear factor (erythroid-derived 2)-like 2 (Nrf2) role as a master defense against hepatotoxicity produced by various chemicals has been investigated in several studies. Nrf2 belongs to the cap ' $n$ ' collar family of transcription factors that promotes transcription of a battery of cytoprotective genes(Aleksunes \& Manautou, 2007; Kensler et al., 2007). Under 
basal conditions, Nrf2 is largely bound to the cytoskeletal anchoring protein Kelch-like ECH-associated protein 1 (Keap1) also known as cytosolic Nrf2 inhibitor in the cytoplasm.In response to oxidative stress, Nrf2 is released from Keap1 andtranslocatesto the nucleus. In the nucleus, Nrf2 binds to the GTGACA***GC core sequence of the antioxidant response element (ARE) (Rushmore et al., 1991) and promotes ARE-mediated antioxidant gene expression.

A low toxic APAP dose causes nuclear accumulation of Nrf2 in mouse liver, which is accompanied by increased expression of Nrf2 dependent cytoprotectivegenes such as heme oxygenase-1 (Hmoxl), NAD(P)H:quinone oxidoreductase-1 (Nqol) and glutamate cysteine ligase catalytic subunit (Gclc) (Aleksunes et al., 2005; Aleksunes et al., 2006; Bauer et al., 2000; Chiu et al., 2002; Goldring et al., 2004). Similar results have been reported with ANIT, BDL, $\mathrm{CCl}_{4}$ and $\mathrm{AlOH}$, other models of hepatic oxidative stress used in the present study(Aleksunes et al., 2005; Aleksunes et al., 2006; Liu et al., 2013; Randle et al., 2008; Tanaka et al., 2009). On the other hand, Nrf2 KO mice are more susceptible to APAPinduced liver injury compared to their wild-type counterparts (Chan et al., 2001; Enomoto et al., 2001). Likewise, $\mathrm{Nrf} 2 \mathrm{KO}$ mice arealso more susceptible to $\mathrm{CCl}_{4}$ - andAlOH-induced hepatoxicity compared towild-type mice (Liu et al., 2013). However, Nrf2 KO mice do not exhibit any difference in susceptibility to either BDL or ANIT treatment(Tanaka et al., 2009; Weerachayaphorn et al., 2012). This response is attributed to the adaptive compensatory changesinvolving nuclear transcription factors, including Fxr, Shp, Pxr andHnfla, efflux bile acid transporters, altered GSH levels and bile flow rates in Nrf2 KO mice (Tanaka et al., 2009; Weerachayaphorn et al., 2012). Collectively, the models of hepatic injury selected for the current study not only result in hepatic oxidative stress but also activate the Nrf2-Keap1 regulatory pathway.

Despite $\mathrm{Fmo3}$ being considered non-inducible, studies with aryl hydrocarbon receptor (AhR) agonists in mice revealed liver Fmo3 gene induction (Celius et al., 2008; Celius et al., 2010). A recent gene array analysis performed in our laboratory also demonstrated Fmo3 gene induction in the APAP autoprotection mouse model (mice receiving a low hepatotoxic APAP dose that become resistant to a subsequent higher APAP dose)(O'Connor et al., 2014).Unlike with AhR agonists that result in marginal increases in Fmo3 protein expression in mouse liver, we showed significant increases in Fmo3 protein levels by 15-fold in APAP autoprotectedmice(Rudraiah et al., 2014). Fmo3 induction by other hepatotoxicants that produce oxidative stress is not currently known.

In human liver, transcription factors regulating constitutive FMO3expression as well as those involved in developmental expression pattern have been extensively studied (Klick \& Hines, 2007; Klick et al., 2008; Shimizu et al., 2008). Because the mammalian FMOs were considered non-inducible by xenobiotics (Cashman \& Zhang, 2002; Krueger \& Williams, 2005), the transcriptional regulation of FMO involving stress-activated transcription factorsor receptors that bind ligands andinteract with DNAwas not studied as other forms of regulation. Thus, little is known about the transcriptional regulation of Fmo3 in response to toxicant exposure. Recently, Celius et al. (2010) showed that the Fmo3 mRNA up-regulation by 3-methylcholanthrene (3MC) and benzo(a)pyrene (BaP) but not TCDD in Hepa-1 cells is 
mediated by p53 and its binding to a p53-response element in the promoter region of Fmo3(Celius et al., 2010).

Differentially expressed genes in the APAP autoprotection model were further analyzed usingCausal Reasoning Engine (CRE), a recently developed computational platform (O'Connor et al., 2014). CRE analysis provides hypotheses on the upstream molecular events that best explain gene expression profiles based on prior biological knowledge. CRE analysis of differentially expressed genes in APAP autoprotection study supportsan induction of the $\mathrm{Nrf} 2$ pathway (O'Connor et al., 2014). Additionally, the 5'-flanking region of the mouse Fmo3 contains multiple copies of the ARE (Celius et al., 2008). Therefore, the purpose of the present study was to investigate liver Fmo3gene expression under oxidative stress conditions involving activation of the Nrf2-Keap1 regulatory pathway. Mice were dosed with hepatotoxicants APAP(400 mg/kg, 24 to 48h), ANIT (50 mg/kg, 2 to 48h), $\mathrm{CCl}_{4}(10$ or $30 \mu \mathrm{L} / \mathrm{kg}, 24$ and $48 \mathrm{~h}$ ) or $\mathrm{AlOH}$ (30 or $60 \mathrm{mg} / \mathrm{kg}, 6$ and $24 \mathrm{~h}$ )orunderwent sham surgery or bile duct ligation (10d). Doses selected for hepatotoxicants are based upon previous studies conducted in our laboratory resulting in oxidative stress and tissue injury. The inclusion of multiple time-points followinghepatotoxicantsexposure enabled comprehensive characterization of temporal changes in $\mathrm{Fmo3}$ in relation to injury and recovery. Further, in order to investigate whether Nrf2 mediates $F m o 3$ gene expression, Nrf2 $\mathrm{KO}$ mice were employed. APAP was used as a model toxicant in the Nrf2 KO mice study. From these experiments,it is concluded that not all hepatotoxicantsthat produce oxidative stress in mice induce liver Fmo3 gene expression. Toxic ANIT treatment, along with the previously demonstrated APAP treatment, markedly increases Fmo3 gene expression. While BDL increases Fmo3 mRNA expression, protein levels do not change.APAP treatment induces $\mathrm{Fmo} 3$ gene expression in Nrf2 $\mathrm{KO}$ mice liver suggesting that the transcriptional regulation of $\mathrm{Fmo3}$ might not involve Nrf2.

\section{Materials and Methods}

\subsection{Chemicals}

Acetaminophen, alpha-naphthylisothiocyanate, carbon tetrachloride, allyl alcohol, propylene glycol and corn oil were purchased from Sigma-Aldrich (St Louis, MO). All other reagents were of reagent grade or better and commercially available.

\subsection{Animals}

Male C57BL/6J mice (9- to10-week old)were purchased from Jackson Laboratories (Bar Harbor, ME) for this study. Upon arrival, mice were acclimated for one week prior to experimentation. Mice were housed in a temperature-, light- and humidity-controlled environment. Mice were fed laboratory rodent diet (Harlan Teklad 2018, Madison, WI) ad libitum.

2.2.1 Experimental Design 1-The primary objective of experimental design 1 was to evaluate liver Fmo3 gene expression under oxidative stress conditions involving activation of the Nrf2-Keap1 regulatory pathway. All hepatotoxicant treatments were performed after an overnight fast, and mice were re-fed $8 \mathrm{~h}$ after treatment. Each treatment group consisted 
of six mice. For APAP treatment, mice were treated with APAP (400 mg/kg, ip) in $50 \%$ propylene glycol or vehicle only (dosing volume: $5 \mathrm{~mL} / \mathrm{kg}$ ). Animals were sacrificed by decapitation at 24, 48 and $72 \mathrm{~h}$ after treatment and blood and livers were collected for analysis. For ANIT treatment, mice were administered ANIT (50 mg/kg, po) in corn oil or vehicle only (dosing volume: $10 \mathrm{~mL} / \mathrm{kg}$ ). At 2, 4, 8, 12, 24 and $48 \mathrm{~h}$ after treatment, mice were sacrificed by decapitation for collecting samples. For CCl4 treatment, groups of mice were injected CCl4 (10 or $30 \mu \mathrm{L} / \mathrm{kg}$, ip) in corn oil or vehicle only (dosing volume: 6 $\mathrm{mL} / \mathrm{kg}$ ) and 24 and $48 \mathrm{~h}$ after treatment, mice were sacrificed by decapitation to collect blood and livers for analysis. For AlOH treatment, mice were administered $\mathrm{AlOH}$ (30 or 60 $\mathrm{mg} / \mathrm{kg}$, ip) in saline or vehicle only (dosing volume: $10 \mathrm{~mL} / \mathrm{kg}$ ). Animals were sacrificed by decapitation at 6 and $24 \mathrm{~h}$ after treatment for sample collection and analysis. BDL liver samples were obtained from a previously described cohort (Donepudi et al., 2012). Briefly, sham or BDL surgery was performed under phenobarbital-induced anesthesia $(65 \mathrm{mg} / \mathrm{kg}$, ip). The surgeries were performed at the University of Rhode Island, College of Pharmacy animal facility with IACUC approval. Serum and liver were collected $10 \mathrm{~d}$ after surgery for analysis.

2.2.2 Experimental Design 2-The goal of experimental design 2 was to investigate whether Nrf2 mediateschanges in liverFmo3 gene expression. APAP was used as a model toxicant for Nrf2 activation.Nrf2 KO mice with a C57BL/6J background werekindly provided by Dr. Angela Slitt from the University of Rhode Island.Following overnight fasting, male Nrf2KO mice $(\mathrm{n}=6)$ and their wild-type counterparts $(\mathrm{C} 57 \mathrm{BL} / 6 \mathrm{~J})(\mathrm{n}=6)$ were treated with APAP ( $400 \mathrm{mg} / \mathrm{kg}$, ip) in $50 \%$ PG or vehicle (dosing volume: $5 \mathrm{~mL} / \mathrm{kg}$ ). Plasma and livers were collected $72 \mathrm{~h}$ after APAP treatment for analysis.

All animal studies were performed in accordance with National Institute of Health standards and the Guide for the Care and Use of Laboratory Animals. This work was approved by the University of Connecticut's Institutional Animal Care and Use Committee.

\subsection{Alanine Aminotransferase (ALT) Assay}

Plasma or serum ALT activity was determined as a biochemical indicator of hepatocellular injury. Infinity ALT Liquid Stable Reagent (Thermo Fisher Scientific Inc., Waltham, MA) was used to determine ALT activity. Briefly, $100 \mu \mathrm{L}$ of reagent was added to $10 \mu \mathrm{L}$ serum or plasma samples, and absorbance was measured spectrophotometrically at 340 nmusing a Bio-Tek Power Wave X Spectrophotometer. ALT activity (IU/L) was determined using the molar extinction coefficient of NADH $\left(6.3 \mathrm{mM}^{-1} \mathrm{~cm}^{-1}\right)$.

\subsection{Total Bile acid Assay}

Total bile acids were extracted from whole liver homogenates using a t-butanol extraction method. Briefly, livers were homogenized in extraction solution (1:1, water: tbutanol) and bile acids extracted overnight at room temperature in the dark. Blood levels of total bile acid and hepatic bile acid levels were measured using a spectrophotometric bile acid assay kit (Bioquant, San Diego, CA) according to manufacturer's protocol. 


\subsection{RNA Isolation and Quantitative Real-Time Polymerase Chain Reaction (qRT-PCR)}

Total RNA was extracted from mouse liver samples using TRIzol reagent (Life Technologies, Carlsbad, CA) according to the manufacturer's instructions. Total RNAwas then reverse-transcribed into cDNA using an M-MLV RT kit (Invitrogen, Carlsbad, CA). Fmo3 mRNA expression was quantified by the $\Delta \Delta \mathrm{CT}$ method and normalized to two housekeeping genes, $\beta$-actin and ribosomal protein S18. Data presented were normalized to $\beta$-actin. Primer pairs were synthesized by Integrated DNA Technologies (Coralville, IA) and are as follow: Fmo3 forward: 5'-GGA AGA GTT GGT GAA GAC CG-3', reverse: 5'-CCC ACA TGC TTT GAG AGG AG-3'. Amplification was performed using an Applied Biosystems 7500 Fast Real-Time PCR System. Amplification was carried out in a $20 \mu \mathrm{L}$ reaction volume containing $8 \mu \mathrm{L}$ diluted cDNA, Fast SYBR Green PCR Master Mix (Applied Biosystems, Foster City, CA) and $1 \mu \mathrm{M}$ of each primer.

\subsection{Preparation of Microsomal Fraction and Western Blot Analysis}

Microsomes were isolated from livers as described previously (Cashman \&Hanzlik, 1981; Rudraiah et al., 2014) and stored at $-80^{\circ} \mathrm{C}$ until use. Protein concentration was determined by the method of Lowry using Bio-Rad protein assay reagents (Bio-Rad Laboratories, Hercules, CA). For western blot analysis, microsomal proteins $(10 \mu \mathrm{g})$ were electrophoretically resolved using 10\% polyacrylamide gels and transferred onto PVDF-Plus membrane (Micron Separations, Westboro, MA). Membranes were blocked with $5 \%$ nonfat powdered milk in tris buffered saline containing $0.05 \%$ tween-20(TBS-T) for $8 \mathrm{~h}$. A rabbit anti-mouse Fmo3 primary antibody (GenScript USA Inc., NJ) (1:5000) was used to detect Fmo3 with $\beta$-actin as a loading control. Blots were then incubated with HRP conjugated secondary antibodies against rabbit IgG (1:2000) (Sigma-Aldrich, St Louis, MO). Protein-antibody complexes were detected using a chemiluminescent kit (Thermo Scientific, IL) with visualization using GeneMate blue autoradiography film (Bioexpress, Kaysville, UT). Precision plus protein dual color standards molecular weight marker (BioradLaboratories, Hercules, CA) was used to identify Fmo3 protein on the blot and microsomal protein isolated from naïve female mouse liver was used as a positive control.

\subsection{Enzyme Assay}

Methimazole (MMI) metabolism was determined spectrophotometrically by measuring the rate of MMI $S$-oxygenation via the reaction of the oxidized product with nitro-5thiobenzoate (TNB) to generate 5,5'-dithiobis(2-nitrobenzoate) (DTNB). The incubation mixture consisted of $50 \mathrm{mM}$ sodium phosphate buffer ( $\mathrm{pH} 9.0$ ), $0.5 \mathrm{mM} \mathrm{NADP}^{+}, 0.5 \mathrm{mM}$ glucose-6-phosphate, $1.5 \mathrm{IU} / \mathrm{mL}$ glucose-6-phosphate dehydrogenase, $0.06 \mathrm{mM}$ DTNB, 0.04 mMdithiothreitol and 100 to $150 \mu \mathrm{g} / \mathrm{mL}$ liver microsomes isolated from mice. Reactions were initiated by the addition of different amounts of MMI (substrate), with a concentration range from 1.25 to $800 \mu \mathrm{M}$. Incubations were done in duplicates. The disappearance of the yellow color was measured spectrophotometrically at $412 \mathrm{~nm}$ and specific activity $(\mu \mathrm{M} / \mathrm{min} / \mathrm{mg})$ was determined using the molar extinction coefficient of NADPH (28.2 $\left.\mathrm{mM}^{-1} \mathrm{~cm}^{-1}\right)$. 


\subsection{Statistical Analysis}

The statistical significance between groups was determined using the Student's t-test, oneway ANOVA with Dunnett's post-hoc test or two-way ANOVA followed by the Bonferroni'spost-hoc test. While Student's t-test was used to compare means of two different treatment groups, ANOVA was used to compare the means of more than two treatment groups that are normally distributed with a common variance. All statistical analysis was performed using GraphPad Prism version 4.00 for Macintosh (GraphPad Software, Inc., San Diego, CA). Data are presented as mean \pm standard error (SE), with $\mathrm{p}<0.05$ considered statistically significant.

\section{Results}

\subsection{Plasma ALT Activity in the Mouse Liver Injury Models}

The time-points selected for the single dose APAP $(400 \mathrm{mg} / \mathrm{kg})$ treatment studyin mice were based on the previous studies that demonstrated Fmo3 mRNA and protein peaks at $48 \mathrm{~h}$ and $72 \mathrm{~h}$, respectively(O'Connor et al., 2014; Rudraiah et al., 2014). The hepatotoxicity of a single dose APAP ( $400 \mathrm{mg} / \mathrm{kg})$ at 24, 48 and $72 \mathrm{~h}$ as assessed by plasma ALT activity has been reported previously (Rudraiah et al., 2014). Briefly, APAP increased plasma ALT activity to $191 \pm 18$ and $219 \pm 47 \mathrm{IU} / \mathrm{L}$ at 24 and $48 \mathrm{~h}$, respectively (mean plasma ALT activity in control mice was $25 \pm 5 \mathrm{IU} / \mathrm{L}$ ). Plasma ALT activity was not statistically different from vehicle controlsby $72 \mathrm{~h}$, indicating recovery from APAP-induced liver injury.Plasma ALT activity in all mouse models of liver injury is shown in Figure 1. ANIT increased ALT activity at $12 \mathrm{~h}(182 \pm 9 \mathrm{IU} / \mathrm{L})$, which continued to increase at 24 and $48 \mathrm{~h}(715 \pm 126 \mathrm{IU} / \mathrm{L}$

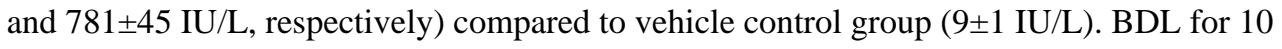
$\mathrm{d}$ results in an elevation of ALT activity to $185 \pm 10 \mathrm{IU} / \mathrm{L}$. A high $\mathrm{CCl}_{4}$ dose $(30 \mu \mathrm{L} / \mathrm{kg})$ increased plasma ALT at 24 and $48 \mathrm{~h}$ to $6367 \pm 1135$ and $397 \pm 111 \mathrm{IU} / \mathrm{L}$, respectively. A low $\mathrm{CCl}_{4}$ dose $(10 \mu \mathrm{L} / \mathrm{kg})$ also increased plasma ALT activity at 24 and $48 \mathrm{~h}$ to $757 \pm 106$ and $416 \pm 68 \mathrm{IU} / \mathrm{L}$, respectively. The greatest increase in plasma ALT with both doses of $\mathrm{CCl}_{4}$ is observed at $24 \mathrm{~h}$. While AlOHtreatment (low dose, $30 \mathrm{mg} / \mathrm{kg}$ ) did not result in significant increases in ALT levels at $6 \mathrm{~h}$ and $24 \mathrm{~h}(36 \pm 4$ and $73 \pm 24 \mathrm{IU} / \mathrm{L}$, respectively),a high AlOHdose $(60 \mathrm{mg} / \mathrm{kg})$ results in significantly higher ALT levels at both $6 \mathrm{~h}$ and $24 \mathrm{~h}$ $(153 \pm 50$ and $4440 \pm 2428$ IU/L, respectively). The associated histopathological damage with all hepatotoxicants has been reported previously(Aleksunes et al., 2005; Aleksunes et al., 2006; Campion et al., 2009; Donepudi et al., 2012; Rudraiah et al., 2014). With acute toxicity models, plasma ALT activity lesser than $1000 \mathrm{IU} / \mathrm{L}$ is usually associated with a minimal to mild hepatocellular damage (histological grade of 2 or less than 2), and an ALT activity higher than $1000 \mathrm{IU} / \mathrm{L}$ is associated with moderate, marked or severe hepatocellular damage (histological grade of 3, 4, or 5) (Aleksunes et al., 2008; Manautou et al., 1994). Alternatively, a $10 \mathrm{~d}$ BDL with an associated ALT activityof less than $200 \mathrm{IU} / \mathrm{L}$, exhibit a chronic hepatocellular damage involving fibrosis (Donepudi et al., 2012).

\subsection{Hepatic Bile Acid Concentrations in the Mouse Liver Injury Models}

To determine the extent of cholestasis induced by different hepatotoxicants used in the current study, total hepatic bile acid levels were measured (Figure 2). As expected ANIT increased hepatic bile acid levels to $1.7 \pm 0.2$ and $1.6 \pm 0.4 \mu \mathrm{mol} / \mathrm{g}$ at 24 and $48 \mathrm{~h}$, respectively, 
compared to $0 \mathrm{~h}$ vehicle control group $(0.2 \pm 0.02 \mu \mathrm{mol} / \mathrm{g})$. BDL also increased hepatic bile acid concentrations to $19.49 \pm 0.85 \mu \mathrm{mol} / 100 \mathrm{mg}$ compared to sham operated group $(10.61 \pm 1.65 \mu \mathrm{mol} / \mathrm{g})$. No significant changes were observed in mice treated with APAP, $\mathrm{CCl}_{4}$ and $\mathrm{AlOH}$.

\subsection{Total bile Acid Concentrations in the Blood in the Mouse Liver Injury Models}

Bile acid concentration in plasma is also a biomarker of cholestasis. In order to determine the extent of cholestasis,plasma bile acid levels were also quantified in all mouse models of liver injury (Figure 3). Plasma bile acid concentration increased in ANIT treated mice at 24 and $48 \mathrm{~h}$ to $210 \pm 20$ and $330 \pm 128 \mu \mathrm{mol} / \mathrm{L}$, respectively, compared with vehicle treated mice $(2 \pm 0.2 \mu \mathrm{mol} / \mathrm{L})$. Bile duct ligation significantly increased serum bile acid levels to $1359 \pm 142$ $\mu \mathrm{mol} / \mathrm{L}$ compared to sham operated mice $(86 \pm 11 \mu \mathrm{mol} / \mathrm{L})$. Significant increases in plasma bile acid concentrationsare seen in high dose $\mathrm{CCl}_{4}$ treated mice at both 24 and $48 \mathrm{~h}(112 \pm 15$ $\mu \mathrm{mol} / \mathrm{Land} 29 \pm 2 \mu \mathrm{mol} / \mathrm{L}$, respectively). Exposure to APAP and AlOH did not result in any significant change in plasma bile acid levels.

\subsection{Hepatic Fmo3 mRNA Expression in the Mouse Liver Injury Models}

Fmo3 mRNA levels were quantified by qRT-PCR and the results are presented in Figure 4. Fmo3 mRNA expression following a single dose APAP $400 \mathrm{mg} / \mathrm{kg}$ treatment has been previously reported (Rudraiah et al., 2014). Briefly, Fmo3 mRNA levelsincreased by 5 $\pm 2.6-$ and 23 \pm 5 .6-fold, at 24 and $48 \mathrm{~h}$ after APAP, respectively, compared to the $0 \mathrm{~h}$ control group. ANIT increased Fmo3 mRNA levels as early as $2 \mathrm{~h}$ after treatment. This increase peaked and is statistically significant only at $12 \mathrm{~h}$ (43 \pm 10 -fold increase), compared to $0 \mathrm{~h}$ vehicle control group. BDL also increased Fmo3 mRNA expression by $1899 \pm 625$-fold, compared to sham operated mice. Both the low and high dose of $\mathrm{CCl}_{4}$ decreased Fmo3 mRNA levels at both time-points examined, and this decrease is statistically significant only at $48 \mathrm{~h}$ (10 $\mu \mathrm{L} / \mathrm{kg}$ : $0.2 \pm 0.06$-fold and $30 \mu \mathrm{L} / \mathrm{kg}$ : 0.2 \pm 0.08 -fold). No change in liver Fmo3 mRNA levels was observed with $\mathrm{AlOH}$ treatment.

\subsection{Fmo3 Protein Expression in the Mouse Liver Injury Models}

Temporal expression of the Fmo3 protein following exposure to hepatotoxicants and BDL were quantified by western blotting. Representative blots and associated densitometric analyses are shown in Figure 5. Fmo3 protein increase following APAP treatment has been previously reported (Rudraiah et al., 2014). Although the expression of Fmo3 protein tended to increase by $1.1 \pm 0.3$-to $1.6 \pm 0.2$-fold between 24 and $72 \mathrm{~h}$ after APAP, the increase is statistically significant only at $72 \mathrm{~h}$. Consistent with Fmo3 mRNA changes evidenced with ANIT treatment, Fmo3 protein levels also tend to increase as early as $2 \mathrm{~h}$. However, this increase is significant only at $12 \mathrm{~h}(3.5 \pm 0.9$-fold) compared to $0 \mathrm{~h}$ vehicle treated group. Fmo3 protein levels decreased to $0.7 \pm 0.08$ - and $0.3 \pm 0.1$-fold at 24 and $48 \mathrm{~h}$, respectively, after exposure to ANIT. Conversely, in spite of the dramatic increase in Fmo3 mRNA levels after BDL, Fmo3 protein levels did notchange. No significant changes in Fmo3 protein expression are observed with $\mathrm{CCl}_{4}$ orAlOH treatment. 


\subsection{Plasma ALT Activity and Fmo3 mRNA Levels after APAP Treatment in Wild-Type and Nrf2 Knockout Mice}

All models of hepatic injury used in the current study activate the Nrf2-Keap1 regulatory pathway. Furthermore, CRE analysis of differentially expressed genes in our APAP autoprotection study supportedan induction of the Nrf2 pathway (O'Connor et al., 2014). To investigate whether Nrf2 mediatesFmo3 gene expression, APAP was used as a model toxicant for Nrf2 activation in Nrf2 KO and WT mice. Mice were administered a single 400 $\mathrm{mg} / \mathrm{kg}$ APAP dose for $72 \mathrm{~h}$. Dose and time-point selected were based on our single dose APAP study performed previously (Rudraiah et al., 2014), wherea $400 \mathrm{mg} / \mathrm{kg}$ APAP treatment increased Fmo3 protein levels at $72 \mathrm{~h}$. Administration of $400 \mathrm{mg} / \mathrm{kg}$ APAP to male C57B1/6J WT mice did not resultin significantlydifferent plasma ALT values at $72 \mathrm{~h}$ from vehicle controls. This is consistent with the previously reported results, indicating recovery from APAP-induced liver injury and increased Fmo3 protein expression in WT mice (Rudraiah et al., 2014). In contrast, plasma ALT activity is elevated at $72 \mathrm{~h}$ in Nrf2 KO mice receiving the same dose of APAP $(176 \pm 12 \mathrm{IU} / \mathrm{L})$ compared to vehicle control group $(23 \pm 5 \mathrm{IU} / \mathrm{L})$ (Figure 6A). This is again consistent with the literature and confirms that Nrf2 plays animportant role not only in the magnitude of toxicity, but also the degree and rate of recovery from APAP-induced liver injury. Fmo3 mRNA levels were quantified by qRTPCR. The results in Figure 6B show that there is no change in Fmo3 mRNA levels at $72 \mathrm{~h}$ in wild-type mice administered $400 \mathrm{mg} / \mathrm{kg}$ APAP. This is again consistent with previous reports, where maximal Fmo3 mRNA expression is seen at $48 \mathrm{~h}$ after APAP administration and returns to normal by $72 \mathrm{~h}$ (Rudraiah et al., 2014). Notably, Fmo3 mRNA expression is significantly higherin Nrf2 KO mice $72 \mathrm{~h}$ after APAP treatment by $140 \pm 43$-fold change compared to vehicle control group.

\subsection{Fmo3 Protein Expression after APAP Treatment in Wild-Type and Nrf2 Knockout Mice}

To examine the temporal changes in Fmo3 gene expression following APAP treatment in WT and Nrf2 KO mice, Fmo3 protein levels were quantified by western blotting and by measuring catalytic activity using MMI as substrate. Representative blots and associated densitometric analysis are shown in Figure 7A. Consistent with increased Fmo3 mRNA expression in Nrf2 KO mice administered APAP $(400 \mathrm{mg} / \mathrm{kg})$ at $72 \mathrm{~h}, \mathrm{Fmo} 3$ protein levels are also significantly higher (5.1 \pm 1.3 -fold) compared to vehicle control group. Measuring FMO catalytic activity using MMI can also quantitate Fmo3 protein induction(Zhang et al., 2007). FMO specific activity increased significantly in Nrf2 KO livers $(48 \pm 6 \pm \mathrm{M} / \mathrm{min} / \mathrm{mg})$ at $72 \mathrm{~h}$ after APAP compared to vehicle controls of either genotype (Figure 7B).

\section{Discussion}

FMO3 is a microsomal enzyme involved in the oxygenation of lipophilic substrates to more polar metabolites. Substrates include nitrogen-, sulfur- and phosphorous-containing drugs and xenobiotics, and most metabolic products of Fmo3 are considered to be nontoxic(Krueger \& Williams, 2005). Although FMOs were discovered in the 1960s (Miller et al., 1960) and further purified in 1972 (Ziegler \& Mitchell, 1972), it was not until 2008 that Fmo3 induction by xenobiotics was demonstrated (Celius et al., 2008; Celius et al., 2010). In these studies, in spite ofa very large increase in Fmo3 mRNA level by AhR agonist 
treatment, only a modest increase in protein level and function was reported. A gene array analysis performed in our laboratory also demonstrated Fmo3gene induction in the mouse model of APAP autoprotection(O'Connor et al., 2014). In this APAP autoprotection mouse model, we showed a significant increase in Fmo3 protein expression and function (Rudraiah et al., 2014). Constitutive Fmo3 expression in a female mouse liver is localized in the areas surrounding the periportal region (Janmohamed et al., 2004; Rudraiah et al., 2014).

Following APAP exposure, the Fmo3 protein expression in APAP autoprotected livers was observed in the centrilobular regions where APAP-induced damage and/or hepatocellular compensatory proliferation is detected. Furthermore, we show that the enhanced expression of Fmo3 confers resistance against APAP-induced hepatotoxicity in mice (Rudraiah et al., 2014).

In the present study, the effect of various other hepatotoxicants on Fmo3 gene expression in male C57BL/6J mouse liver was examined. A unifying theme for all hepatotoxicants used in our study is the oxidative stress. These models of oxidative stress used are very well studied with respect to activation of Nrf2-Keap1 regulatory pathway. This has been repeatedlydemonstrated in our laboratory and in the literature (Aleksunes et al., 2005; Aleksunes et al., 2006; Aleksunes et al., 2006; Bauer et al., 2000; Chiu et al., 2002; Goldring et al., 2004; Liu et al., 2013; Randle et al., 2008; Tanaka et al., 2009). Thus, we were confident that the treatments selected result in oxidative stress and therefore the need for measuring markers of oxidative stress for each experimentalgroup of hepatotoxicity was not deemed necessary.

Coincidentally, all of the hepatotoxicants selected produce cholestasis, with the exception of AlOH(Donepudi et al., 2012; Tanaka et al., 2009; Weerachayaphorn et al., 2012; Yamazaki et al., 2013). Furthermore, perturbation of bile acid homeostasis has been demonstrated to be an early event in the pathogenesis of drug induced liver injury(Yamazaki et al., 2013). To determine whether accumulation of bile acids is a signaling event regulating Fmo3, we measured total hepatic and plasma bile acid levels. Consistent with the literature, ANIT and BDL increased plasma and hepatic bile acid concentrations. A high $\mathrm{CCl}_{4}$ dose did not significantly alter liver bile acid levels, but significantly increased plasma bile acid concentration. APAP tended to increase both hepatic and plasma bile acid concentrations, but this is not statistically significant.

In general, ANIT and BDL-mediated damage significantly increased liver Fmo3 mRNA expression. While $\mathrm{CCl}_{4}$-mediated liver injury significantly decreased Fmo3 mRNA expression, no change in expression is evidenced with AlOH. Fmo3 mRNA expressionin response to ANIT treatment precedes serum and hepatic bile acid accumulation and the maximal Fmo3 expression (both mRNA and protein) parallels the mild hepatocellular damage observed. This observation argues against the concept that hepatic bile acid accumulation is a pre-requisite for Fmo3 gene expression changes in the ANIT model. With BDL, unlike ANIT, Fmo3 mRNA induction is associated with higher serum and hepatic bile acid levels, but protein level does not change. Since tissues were analyzed 10 days after BDL, we do not have a sense of what the temporal relationship is between hepatic bile acid accumulation and elevated Fmo3 mRNA induction. This relationship deserves further attention based on the discussion of FXR signaling that can be found below. 
Overt ANIT-induced hepatocellular damage at 24 and $48 \mathrm{~h}$ decreased Fmo3 gene expression and the decease is statistically significant at $48 \mathrm{~h}$ compared to the $12 \mathrm{~h}$ ANIT-treated group. This observation with respect to the relationship between plasma ALT level and Fmo3 gene expression is consistent with our results with APAP hepatotoxicity. We have demonstrated in our APAP autoprotection mouse model that the APAP $(400 \mathrm{mg} / \mathrm{kg})$ pretreated group as well as the autoprotected group (APAP pretreatment: $400 \mathrm{mg} / \mathrm{kg}$, APAP challenge: 600 $\mathrm{mg} / \mathrm{kg}$ ) exhibit average plasma ALT values of about $250 \mathrm{IU} / \mathrm{L}$ and Fmo3 protein induction. The group that receives a toxic APAP dose of $600 \mathrm{mg} / \mathrm{kg}$ exhibits much greater average plasma ALT activity of about 1600 IU/L, but no Fmo3 gene induction (Rudraiah et al., 2014).

One key feature that is consistent with APAP-, BDL- and ANIT-induced liver injury and enhanced Fmo3 gene expression is the magnitude in plasma ALT elevations. Mild ALT elevation is the common feature for all three models where Fmo3 mRNA induction is observed. Although BDL is a chronic injury model, it well known that the ALT values do not correlate well with the severity of liver damage particularly during fibrotic hepatocellular necrosis (Kallai et al., 1964). A similar clinical feature is also seen in cases of primary biliary cirrhosis (BDL models primary biliary cirrhosis in humans) (Hohenester et al., 2009). The lack of Fmo3 protein detection during BDL may be due to signal dilution by fibrotic liver tissue. It is also possible that under oxidative stress conditions some proteins involved in translation are oxidized in vivo inhibiting translation (Shenton et al., 2006). To add to this complexity, in spite of lower plasma ALT activity at $24 \mathrm{~h}$ (low dose $\mathrm{CCl}_{4}$ ), and $48 \mathrm{~h}$ (both high and low dose $\mathrm{CCl}_{4}$ ) with $\mathrm{CCl}_{4}$, there is down-regulation of $\mathrm{Fmo3}$ gene expression. In AlOH-treated livers, lower plasma ALT activity did not show any change in Fmo3 gene expression. This is suggestive of an unknown underlying mechanism unique to APAP, ANIT and BDL, which is contributing to Fmo3 mRNA induction. Studies are necessary to investigate the regional distribution of $\mathrm{Fmo3}$ protein expression during ANITand BDL-induced liver injury to determine whether the protein expression in these models is localized to the portal vein, where ANIT- and BDL-induced hepatotoxicity is confined. Collectively, these data suggest that there is a threshold for degree of hepatic injury that results in increased $\mathrm{Fmo3}$ gene and protein expression.More specifically,these data suggest that acute moderate or mild hepatotoxicity is optional for Fmo3 induction, while chronic, severe hepatotoxicity is not.

As discussed before, all models of hepatic injury used in the current study result in hepatic oxidative stress and activate the Nrf2-Keap1 regulatory pathway. Importantly, CRE analysis of differentially expressed genes in our APAP autoprotection study supportedan induction of the Nrf2 pathway (O'Connor et al., 2014). Additionally, Celius et al. (2008) showed that the 5'-flanking region of the mouse Fmo3 contains multiple copies of the ARE (Celius et al., 2008). Promoter analysis of mouse $F m o 3$ promoter (7 kb length)using MatInspector software (Genomatix, Munich, Germany), also showed an ARE at about $3 \mathrm{~kb}$ from the transcription start site (data not shown). We also found two other binding sites for Bach1, at $600 \mathrm{bp}$ and $2 \mathrm{~kb}$ from the $F m o 3$ transcription start site (data not shown). Bach1 is a regulatory mediator of $\mathrm{Nrf} 2$, in that it is a transcription repressor. Bach1 heterodimerizes with small Maf proteins in the absence of cellular stress and represses gene expression. In 
the presence of oxidative stress, Bach1 is released from the Maf proteins and is replaced by Nrf2(Kaspar et al., 2009). Thus, using APAP as a model toxicant for Nrf2 activation, Fmo3 gene expression was evaluated inNrf2 $\mathrm{KO}$ mice. Compared to APAP-treated wild-type mice, Nrf2 KO mice exhibit persistent and significant hepatocellular damage $72 \mathrm{~h}$ after APAP administration. Nrf2 KO mice are not only more susceptible to APAP-induced hepatocellular necrosis, but also fail to recover from injury as rapidly as the WT mice. This is consistent with the literature that describes $\mathrm{Nrf} 2$ as a master regulator of many cytoprotective genes involved in APAP-induced hepatotoxicity (Aleksunes et al., 2005; Aleksunes et al., 2006; Bauer et al., 2000; Chiu et al., 2002; Goldring et al., 2004). Finally, Fmo3 gene induction by APAP treatment in Nrf2 null mice suggests that the transcriptional regulation of Fmo3does not involve this transcription factor. The persistent mild hepatocellular injury and oxidative stress in Nrf2 KO mice most likely activates other signaling mechanisms involved in $\mathrm{Fmo3}$ gene induction.

Future studies will investigate the role of other nuclear receptors in Fmo3 gene induction. Particularly, farnesoid X receptor (FXR) role in $\mathrm{Fmo3}$ gene induction during APAP hepatotoxicity is worth investigating. FXR is one of the major bile acid sensors in the liver (Chiang, 2002) and plays a protective role during cholestasis development. Recently, it is shown that activation of FXR induces Fmo3 protein function (Bennett et al., 2013). Activation of FXR also provides protection against APAP-induced hepatotoxicity(F. Y. Lee et al., 2010). In addition, we discovered three binding sites for farnesoid $X$ receptor-response element (FXRE) at about 1.6, 2.1 and $3.3 \mathrm{~kb}$ from the transcription start site on the mouse Fmo3 promoter (data not shown). Although, Pregnane $\mathrm{X}$ receptor (PXR) is also a bile acid sensor, no binding sites for PXR were found on promoter analysis and furthermore, PXR activation sensitizes APAP-induced hepatotoxicity (Cheng et al., 2009; Guo et al., 2004).

In conclusion, this study comprehensively characterizes for the first time temporal changes in Fmo3 gene expression during different conditions known to impart hepatic oxidative stress. In particular, we show that toxic ANIT and BDL significantly alter Fmo3 mRNA expression, but only Fmo3 protein with ANIT. The reason for this discrepancy is not yet clear or easy to rationalize. It is possible that $\mathrm{Fmo3}$ is also protective during other chemicalinduced liver injury including ANIT. Even though the exact mechanism of Fmo3 gene expression or its role in protecting against toxicant-induced liver injury is not yet clear, the observed toxicity threshold for $\mathrm{Fmo3}$ gene expression is intriguing. This work advances the lack of knowledge with regard to the inducibility of $\mathrm{Fmo}_{3}$ and its potential protective role in drug-induced liver injury.

\section{Acknowledgements}

This work is supported by the National Institutes of Health Grant (DK069557).

\section{Abbreviations}

Fmo3 Flavin-containing monoxygenase-3

APAP Acetaminophen 


$\begin{array}{ll}\text { ANIT } & \text { Alpha-naphthylisothiocyanate } \\ \text { BDL } & \text { Bile duct ligation } \\ \mathbf{C C l}_{4} & \text { Carbon tetrachloride } \\ \text { AlOH } & \text { Allyl alcohol } \\ \text { Nrf2 } & \text { Nuclear factor (erythroid-derived 2)-like 2 }\end{array}$

\section{References}

Aleksunes LM, Campion SN, Goedken MJ, Manautou JE. Acquired resistance to acetaminophen hepatotoxicity is associated with induction of multidrug resistance-associated protein 4 (Mrp4) in proliferating hepatocytes. Toxicological Sciences : An Official Journal of the Society of Toxicology. 2008; 104(2):261-273. [PubMed: 18468992]

Aleksunes LM, Manautou JE. Emerging role of Nrf2 in protecting against hepatic and gastrointestinal disease. Toxicologic Pathology. 2007; 35(4):459-473. [PubMed: 17562481]

Aleksunes LM, Scheffer GL, Jakowski AB, Pruimboom-Brees IM, Manautou JE. Coordinated expression of multidrug resistance-associated proteins (mrps) in mouse liver during toxicantinduced injury. Toxicological Sciences : An Official Journal of the Society of Toxicology. 2006; 89(2):370-379. [PubMed: 16177239]

Aleksunes LM, Slitt AL, Maher JM, Dieter MZ, Knight TR, Goedken M, et al. Nuclear factor-E2related factor 2 expression in liver is critical for induction of $\mathrm{NAD}(\mathrm{P}) \mathrm{H}$ :Quinoneoxidoreductase 1 during cholestasis. Cell Stress \& Chaperones. 2006; 11(4):356-363. [PubMed: 17278884]

Aleksunes LM, Slitt AM, Cherrington NJ, Thibodeau MS, Klaassen CD, Manautou JE. Differential expression of mouse hepatic transporter genes in response to acetaminophen and carbon tetrachloride. Toxicological Sciences : An Official Journal of the Society of Toxicology. 2005; 83(1):44-52. [PubMed: 15496496]

Bauer I, Vollmar B, Jaeschke H, Rensing H, Kraemer T, Larsen R, et al. Transcriptional activation of heme oxygenase- 1 and its functional significance in acetaminophen-induced hepatitis and hepatocellular injury in the rat. Journal of Hepatology. 2000; 33(3):395-406. [PubMed: 11019995]

Bennett BJ, de AguiarVallim TQ, Wang Z, Shih DM, Meng Y, Gregory J, et al. Trimethylamine-Noxide, a metabolite associated with atherosclerosis, exhibits complex genetic and dietary regulation. Cell Metabolism. 2013; 17(1):49-60. [PubMed: 23312283]

Burcham PC, Fontaine F. Extensive protein carbonylation precedes acrolein-mediated cell death in mouse hepatocytes. Journal of Biochemical and Molecular Toxicology. 2001; 15(6):309-316. [PubMed: 11835630]

Campion SN, Tatis-Rios C, Augustine LM, Goedken MJ, van Rooijen N, Cherrington NJ, et al. Effect of allyl alcohol on hepatic transporter expression: Zonal patterns of expression and role of kupffer cell function. Toxicology and Applied Pharmacology. 2009; 236(1):49-58. [PubMed: 19371622]

Cashman JR, Hanzlik RP. Microsomal oxidation of thiobenzamide.A photometric assay for the flavincontaining monooxygenase. Biochemical and Biophysical Research Communications. 1981; 98(1):147-153. [PubMed: 7213381]

Cashman JR, Zhang J. Interindividual differences of human flavin-containing monooxygenase 3: Genetic polymorphisms and functional variation. Drug Metabolism and Disposition: The Biological Fate of Chemicals. 2002; 30(10):1043-1052. [PubMed: 12228178]

Celius T, Pansoy A, Matthews J, Okey AB, Henderson MC, Krueger SK, et al. Flavin-containing monooxygenase-3: Induction by 3-methylcholanthrene and complex regulation by xenobiotic chemicals in hepatoma cells and mouse liver. Toxicology and Applied Pharmacology. 2010; 247(1):60-69. [PubMed: 20570689]

Celius T, Roblin S, Harper PA, Matthews J, Boutros PC, Pohjanvirta R, et al. Aryl hydrocarbon receptor-dependent induction of flavin-containing monooxygenase mRNAs in mouse liver. Drug 
Metabolism and Disposition: The Biological Fate of Chemicals. 2008; 36(12):2499-2505. [PubMed: 18765683]

Chan K, Han XD, Kan YW. An important function of Nrf2 in combating oxidative stress: Detoxification of acetaminophen. Proceedings of the National Academy of Sciences of the United States of America. 2001; 98(8):4611-4616. [PubMed: 11287661]

Cheng J, Ma X, Krausz KW, Idle JR, Gonzalez FJ. Rifampicin-activated human pregnane X receptor and CYP3A4 induction enhance acetaminophen-induced toxicity. Drug Metabolism and Disposition: The Biological Fate of Chemicals. 2009; 37(8):1611-1621. [PubMed: 19460945]

Chiang JY. Bile acid regulation of gene expression: Roles of nuclear hormone receptors. Endocrine Reviews. 2002; 23(4):443-463. [PubMed: 12202460]

Chiu H, Brittingham JA, Laskin DL. Differential induction of heme oxygenase-1 in macrophages and hepatocytes during acetaminophen-induced hepatotoxicity in the rat: Effects of hemin and biliverdin. Toxicology and Applied Pharmacology. 2002; 181(2):106-115. [PubMed: 12051994]

Cohen SD, Pumford NR, Khairallah EA, Boekelheide K, Pohl LR, Amouzadeh HR, et al. Selective protein covalent binding and target organ toxicity. Toxicology and Applied Pharmacology. 1997; 143(1):1-12. [PubMed: 9073586]

Donepudi AC, Aleksunes LM, Driscoll MV, Seeram NP, Slitt AL. The traditional ayurvedic medicine, eugeniajambolana (jamun fruit), decreases liver inflammation, injury and fibrosis during cholestasis. Liver International : Official Journal of the International Association for the Study of the Liver. 2012; 32(4):560-573. [PubMed: 22212619]

Enomoto A, Itoh K, Nagayoshi E, Haruta J, Kimura T, O'Connor T, et al. High sensitivity of Nrf2 knockout mice to acetaminophen hepatotoxicity associated with decreased expression of AREregulated drug metabolizing enzymes and antioxidant genes. Toxicological Sciences : An Official Journal of the Society of Toxicology. 2001; 59(1):169-177. [PubMed: 11134556]

Goldring CE, Kitteringham NR, Elsby R, Randle LE, Clement YN, Williams DP, et al. Activation of hepatic Nrf2 in vivo by acetaminophen in CD-1 mice. Hepatology (Baltimore, Md.). 2004; 39(5): 1267-1276.

Guo GL, Moffit JS, Nicol CJ, Ward JM, Aleksunes LA, Slitt AL, et al. Enhanced acetaminophen toxicity by activation of the pregnane $\mathrm{X}$ receptor. Toxicological Sciences : An Official Journal of the Society of Toxicology. 2004; 82(2):374-380. [PubMed: 15456926]

Hohenester S, Oude-Elferink RP, Beuers U. Primary biliary cirrhosis. Seminars in Immunopathology. 2009; 31(3):283-307. [PubMed: 19603170]

Jaeschke H, McGill MR, Ramachandran A. Oxidant stress, mitochondria, and cell death mechanisms in drug-induced liver injury: Lessons learned from acetaminophen hepatotoxicity. Drug Metabolism Reviews. 2012; 44(1):88-106. [PubMed: 22229890]

Janmohamed A, Hernandez D, Phillips IR, Shephard EA. Cell-, tissue-, sex- and developmental stagespecific expression of mouse flavin-containing monooxygenases (fmos). Biochemical Pharmacology. 2004; 68(1):73-83. [PubMed: 15183119]

Kallai L, Hahn A, Roeder V, Zupanic V. Correlation between histological findings and serum transaminase values in chronic diseases of the liver. ActaMedicaScandinavica. 1964; 175:49-56.

Kaspar JW, Niture SK, Jaiswal AK. Nrf2:INrf2 (Keap1) signaling in oxidative stress. Free Radical Biology \& Medicine. 2009; 47(9):1304-1309. [PubMed: 19666107]

Kensler TW, Wakabayashi N, Biswal S. Cell survival responses to environmental stresses via the Keap1-Nrf2-ARE pathway. Annual Review of Pharmacology and Toxicology. 2007; 47:89-116.

Klick DE, Hines RN. Mechanisms regulating human FMO3 transcription. Drug Metabolism Reviews. 2007; 39(2-3):419-442. [PubMed: 17786630]

Klick DE, Shadley JD, Hines RN. Differential regulation of human hepatic flavin containing monooxygenase 3 (FMO3) by CCAAT/enhancer-binding protein beta (C/EBPbeta) liver inhibitory and liver activating proteins. Biochemical Pharmacology. 2008; 76(2):268-278. [PubMed: 18555208]

Krueger SK, Williams DE. Mammalian flavin-containing monooxygenases: Structure/function, genetic polymorphisms and role in drug metabolism. Pharmacology \& Therapeutics. 2005; 106(3): 357-387. [PubMed: 15922018] 
Larson AM, Polson J, Fontana RJ, Davern TJ, Lalani E, Hynan LS, et al. Acetaminophen-induced acute liver failure: Results of a united states multicenter, prospective study. Hepatology (Baltimore, Md.). 2005; 42(6):1364-1372.

Lee FY, de AguiarVallim TQ, Chong HK, Zhang Y, Liu Y, Jones SA, et al. Activation of the farnesoid $\mathrm{X}$ receptor provides protection against acetaminophen-induced hepatic toxicity. Molecular Endocrinology (Baltimore, Md.). 2010; 24(8):1626-1636.

Lee WM. The case for limiting acetaminophen-related deaths: Smaller doses and unbundling the opioid-acetaminophen compounds. Clinical Pharmacology and Therapeutics. 2010; 88(3):289292. [PubMed: 20725075]

Liu J, Wu KC, Lu YF, Ekuase E, Klaassen CD. Nrf2 protection against liver injury produced by various hepatotoxicants. Oxidative Medicine and Cellular Longevity. 2013; 2013:305861. [PubMed: 23766851]

Manautou JE, Hoivik DJ, Tveit A, Hart SG, Khairallah EA, Cohen SD. Clofibrate pretreatment diminishes acetaminophen's selective covalent binding and hepatotoxicity. Toxicology and Applied Pharmacology. 1994; 129(2):252-263. [PubMed: 7992315]

Miller JA, Cramer JW, Miller EC. The N- and ringhydroxylation of 2-acetylaminofluorene during carcinogenesis in the rat. Cancer Research. 1960; 20:950-962. [PubMed: 13853964]

O'Connor MA, Koza-Taylor P, Campion SN, Aleksunes LM, Gu X, Enayetallah AE, et al. Analysis of changes in hepatic gene expression in a murine model of tolerance to acetaminophen hepatotoxicity (autoprotection). Toxicology and Applied Pharmacology. 2014; 274(1):156-167. [PubMed: 24126418]

Ohno Y, Ormstad K, Ross D, Orrenius S. Mechanism of allyl alcohol toxicity and protective effects of low-molecular-weight thiols studied with isolated rat hepatocytes. Toxicology and Applied Pharmacology. 1985; 78(2):169-179. [PubMed: 2930914]

Randle LE, Goldring CE, Benson CA, Metcalfe PN, Kitteringham NR, Park BK, et al. Investigation of the effect of a panel of model hepatotoxins on the Nrf2-Keap1 defence response pathway in CD-1 mice. Toxicology. 2008; 243(3):249-260. [PubMed: 18078705]

Rudraiah S, Rohrer P, Gurevich I, Goedken MJ, Rasmussen T, Hines RN, et al. Tolerance to acetaminophen hepatotoxicity in the mouse model of autoprotection is associated with induction of flavin-containing monooxygenase-3 (FMO3) in hepatocytes. Toxicological Sciences: An Official Journal of the Society of Toxicology. 2014

Rushmore TH, Morton MR, Pickett CB. The antioxidant responsive element.activation by oxidative stress and identification of the DNA consensus sequence required for functional activity. The Journal of Biological Chemistry. 1991; 266(18):11632-11639. [PubMed: 1646813]

Shenton D, Smirnova JB, Selley JN, Carroll K, Hubbard SJ, Pavitt GD, et al. Global translational responses to oxidative stress impact upon multiple levels of protein synthesis. The Journal of Biological Chemistry. 2006; 281(39):29011-29021. [PubMed: 16849329]

Shimizu M, Murayama N, Nagashima S, Fujieda M, Yamazaki H. Complex mechanism underlying transcriptional control of the haplotypedflavin-containing monooxygenase 3 (FMO3) gene in japanese: Different regulation between mutations in $5^{\prime}$-upstream distal region and common element in proximal region. Drug Metabolism and Pharmacokinetics. 2008; 23(1):54-58. [PubMed: 18305374]

Sokol RJ, Winklhofer-Roob BM, Devereaux MW, McKim JM Jr. Generation of hydroperoxides in isolated rat hepatocytes and hepatic mitochondria exposed to hydrophobic bile acids. Gastroenterology. 1995; 109(4):1249-1256. [PubMed: 7557092]

Tanaka Y, Aleksunes LM, Cui YJ, Klaassen CD. ANIT-induced intrahepatic cholestasis alters hepatobiliary transporter expression via Nrf2-dependent and independent signaling. Toxicological Sciences : An Official Journal of the Society of Toxicology. 2009; 108(2):247-257. [PubMed: 19181614]

Tom WM, Fong LY, Woo DY, Prasongwatana V, Boyde TR. Microsomal lipid peroxidation and oxidative metabolism in rat liver: Influence of vitamin A intake. Chemico-Biological Interactions. 1984; 50(3):361-366. [PubMed: 6744472]

Trauner M, Meier PJ, Boyer JL. Molecular pathogenesis of cholestasis. The New England Journal of Medicine. 1998; 339(17):1217-1227. 
Weerachayaphorn J, Mennone A, Soroka CJ, Harry K, Hagey LR, Kensler TW, et al. Nuclear factorE2-related factor 2 is a major determinant of bile acid homeostasis in the liver and intestine.American Journal of Physiology. Gastrointestinal and Liver Physiology. 2012; 302(9):G925-36. [PubMed: 22345550]

Yamazaki M, Miyake M, Sato H, Masutomi N, Tsutsui N, Adam KP, et al. Perturbation of bile acid homeostasis is an early pathogenesis event of drug induced liver injury in rats. Toxicology and Applied Pharmacology. 2013; 268(1):79-89. [PubMed: 23360887]

Zhang J, Cerny MA, Lawson M, Mosadeghi R, Cashman JR. Functional activity of the mouse flavincontaining monooxygenase forms 1, 3, and 5. Journal of Biochemical and Molecular Toxicology. 2007; 21(4):206-215. [PubMed: 17721934]

Ziegler DM, Mitchell CH. Microsomal oxidase. IV. properties of a mixed-function amine oxidase isolated from pig liver microsomes. Archives of Biochemistry and Biophysics. 1972; 150(1):116125. [PubMed: 5028071] 

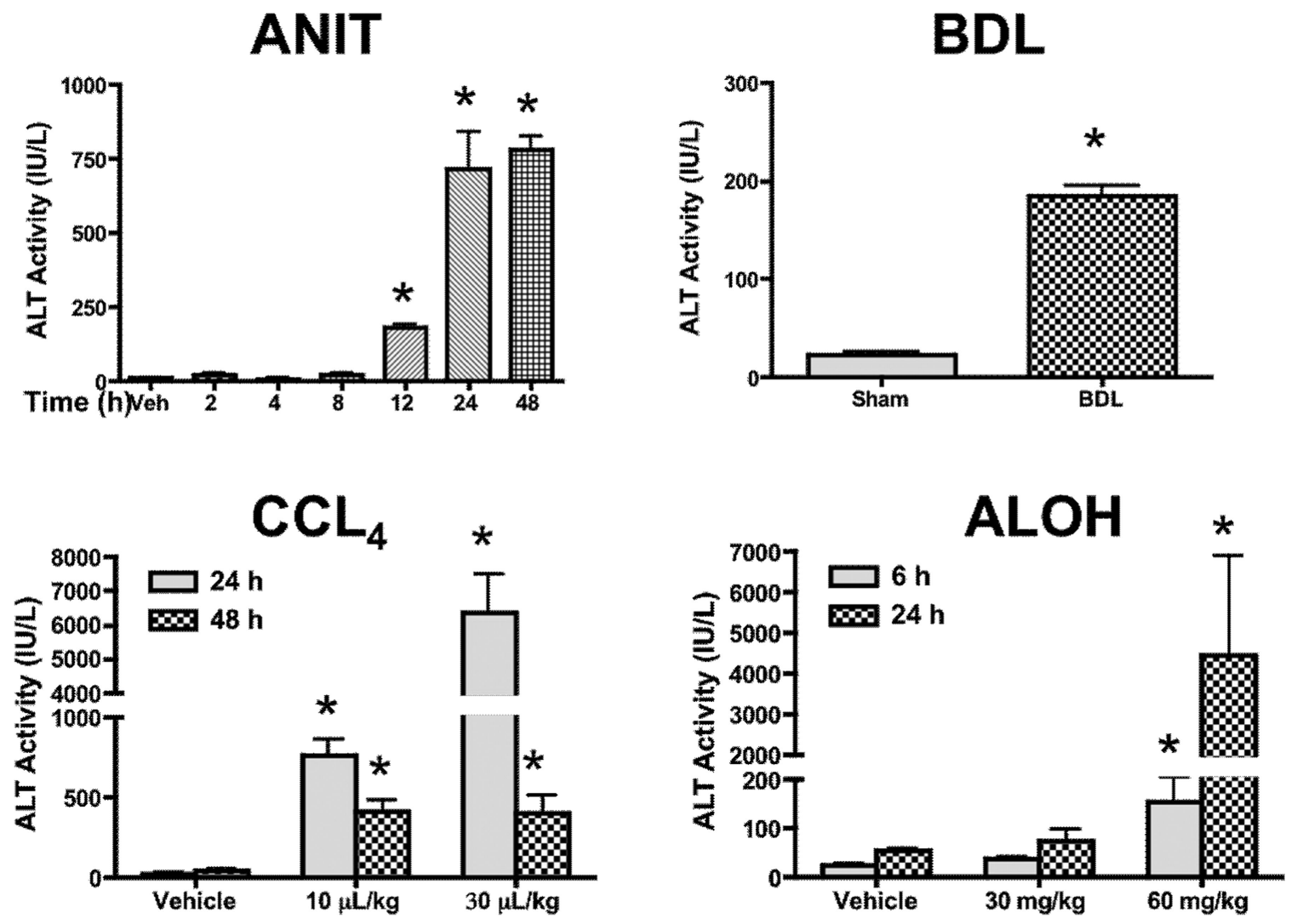

Figure 1. Plasma ALT activity in mice treated with hepatotoxicants or BDL

Male C57BL/6J mice ( $\mathrm{n}=6$ per group) were treated with ANIT $(50 \mathrm{mg} / \mathrm{kg}$, po, 2,4,8,12,24 \& $48 \mathrm{~h}), \mathrm{CCl}_{4}(10 \& 30 \mu \mathrm{L} / \mathrm{kg}, \mathrm{ip}, 24 \& 48 \mathrm{~h}), \mathrm{AlOH}$ (30 \& 60 mg/kg,ip, $6 \& 24$ h) or BDL (10

d). Plasma was collected from mice at various time-points following hepatotoxicant treatment or the appropriate vehicle. The data are presented as mean plasma ALT (IU/L) \pm SE. One-way ANOVA, t-test or two-way ANOVA was performed, appropriately, followed by the Dunnett's posttest for One-way ANOVA and the Bonferroni posttest for two-way ANOVA. Asterisks $(*)$ represent a statistical difference $(\mathrm{p}<0.05)$ between vehicle-treated and hepatotoxicant-treated group. 

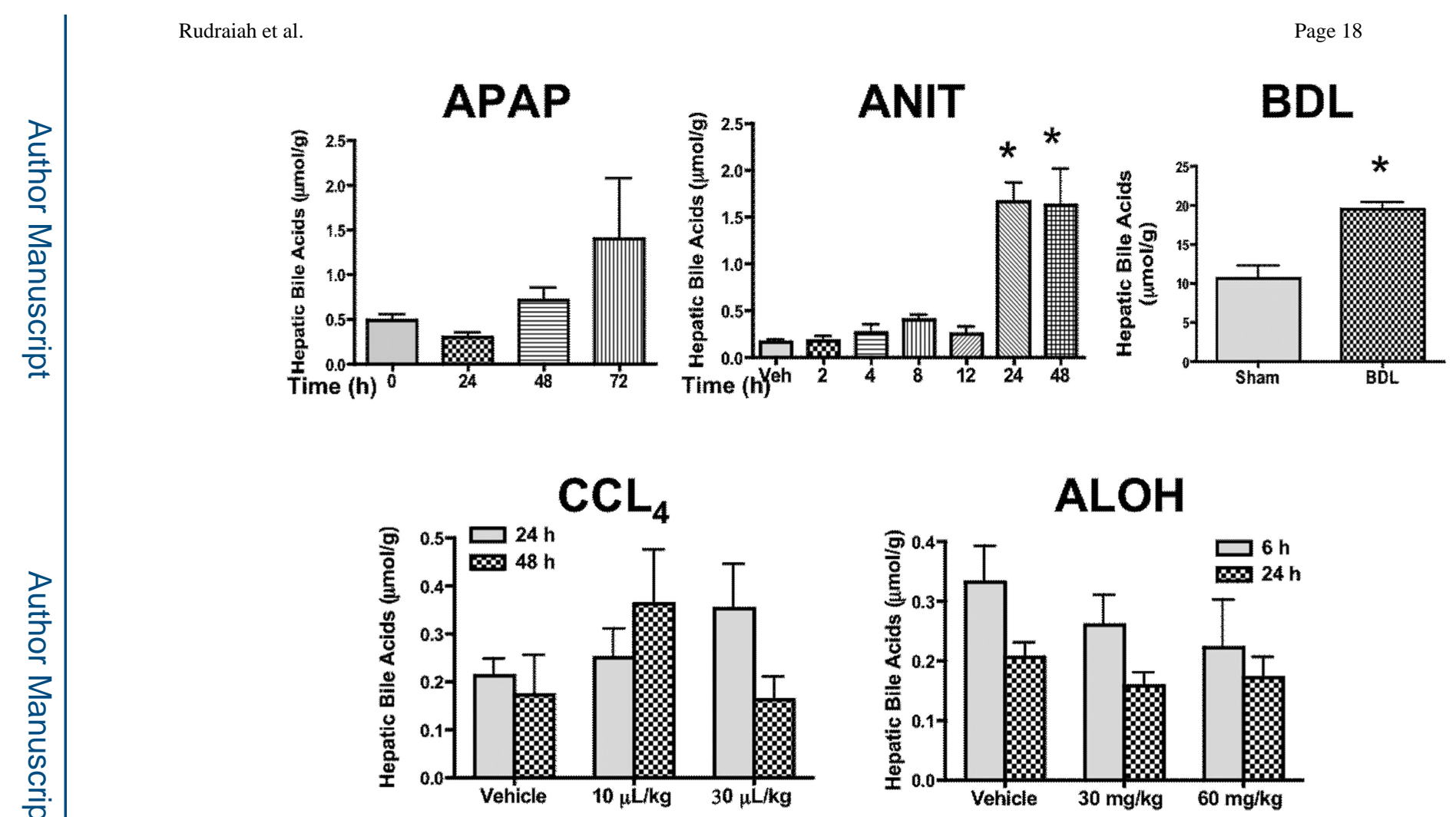

Figure 2. Hepatic bile acid levels after hepatotoxicant administration or BDL

Livers were collected at the end of each study (24, 48 \& 72h for APAP; $2,4,8,12,24$ \& $48 \mathrm{~h}$ for ANIT; $10 \mathrm{~d}$ for BDL; $24 \& 48 \mathrm{~h}$ for $\mathrm{CCl}_{4}$; and $6 \& 24 \mathrm{~h}$ for $\mathrm{AlOH}$ ). Liver total bile acids were measured spectrophotometrically using a commercial bile acid assay kit. Hepatic total bile acids are expressed as mean hepatic bile acids $(\mu \mathrm{mol} / \mathrm{g}) \pm$ SE. One-way ANOVA, t-test or two-way ANOVA was performed, appropriately, followed by the Dunnett's posttest for one-way ANOVA and the Bonferroni posttest for two-way ANOVA. Asterisks (*) represent a statistical difference $(\mathrm{p}<0.05)$ between vehicle-treated and hepatotoxicant-treated or BDL group. 

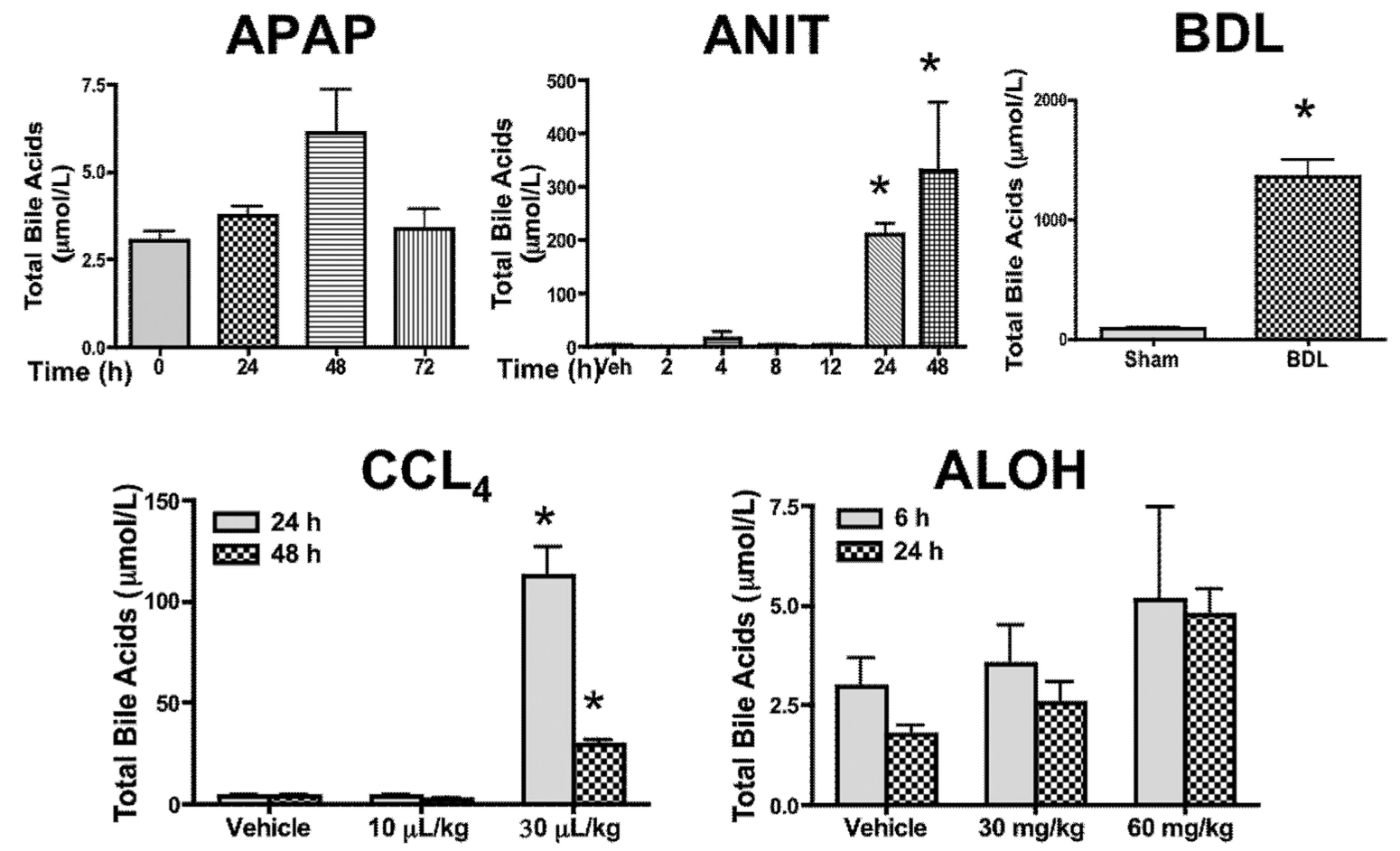

Figure 3. Blood levels of TotalBile acid in the mouse models of liver injury Mice ( $\mathrm{n}=6$ per group) were administered APAP (400 mg/kg, ip, 24, 48 \& 72h), ANIT (50 $\mathrm{mg} / \mathrm{kg}$, po, 2,4,8,12,24 \& 48h), $\mathrm{CCl}_{4}(10 \& 30 \mu \mathrm{L} / \mathrm{kg}, \mathrm{ip}, 24 \& 48 \mathrm{~h}), \mathrm{AlOH}$ (30 \& $60 \mathrm{mg} / \mathrm{kg}$, ip, $6 \& 24 \mathrm{~h}$ ) or BDL (10 d).Blood was collected and the plasma or serum (for BDL) was isolated by centrifugation. Total bile acid levels were measured spectrophotometrically using a commercial bile acid assay kit. Total bile acids are expressed as mean total bile acids $(\mu \mathrm{mol} / \mathrm{L}) \pm \mathrm{SE}$. Student's t-test,one-way ANOVA,or two-way ANOVA was performed, appropriately, followed by the Dunnett's posttest for one-way ANOVA and the Bonferroni posttest for two-way ANOVA. Asterisks (*) represent a statistical difference $(\mathrm{p}<0.05)$ between vehicle-treated and hepatotoxicant-treated or BDL group. 

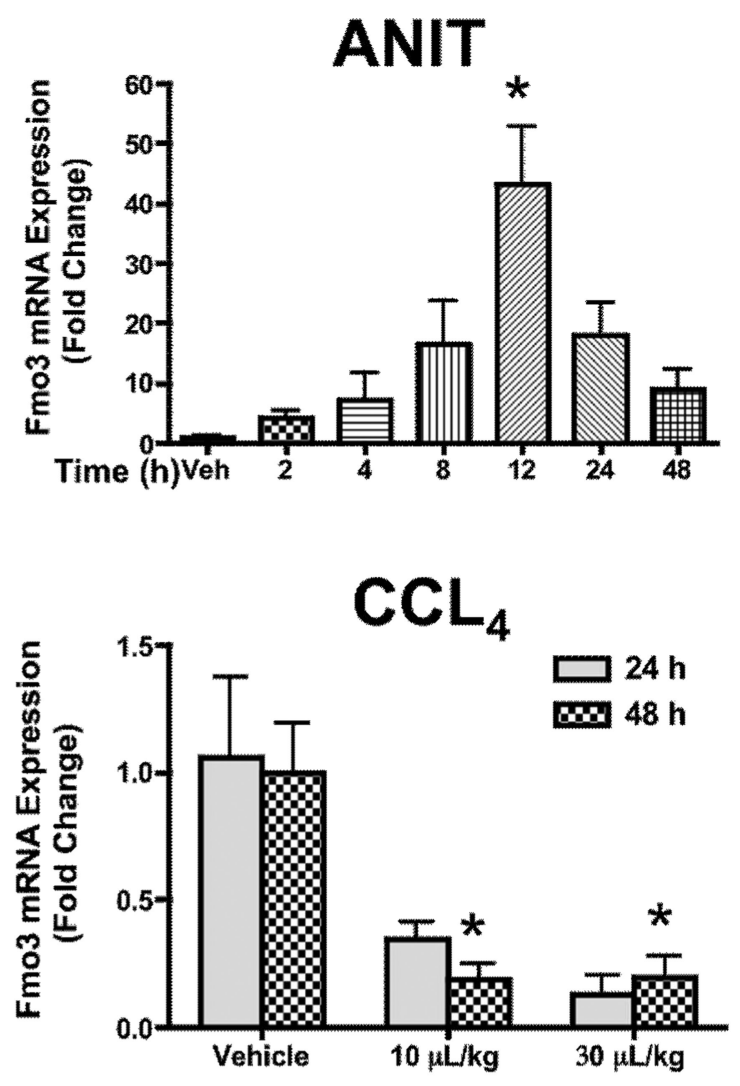

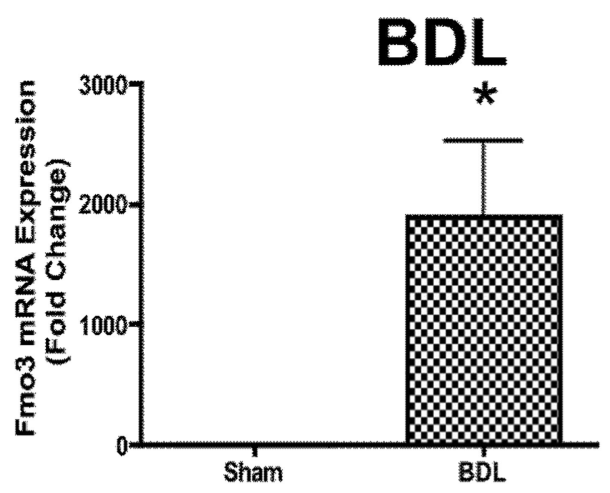

ALOH

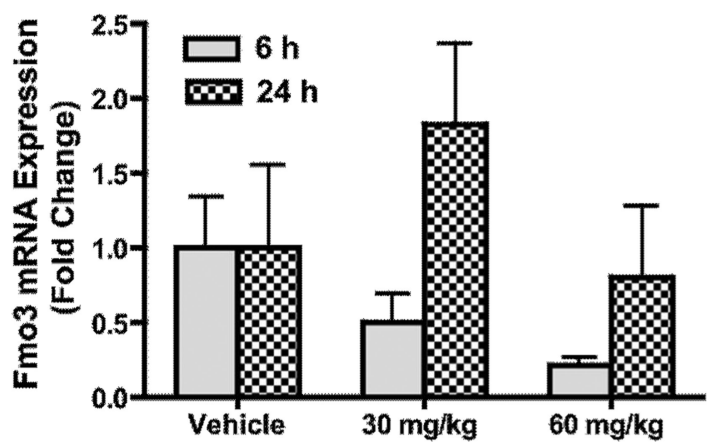

Figure 4. Quantitative RT-PCR analysis of liver Fmo3 transcripts after hepatotoxicant treatment or BDL

Livers were collected from mice $(n=6)$ sacrificed at respective time-points $(2,4,8,12,24 \&$ $48 \mathrm{~h}$ for ANIT; $24 \& 48 \mathrm{~h}$ for $\mathrm{CCl}_{4} ; 6 \& 24 \mathrm{~h}$ for $\mathrm{AlOH}$; and $10 \mathrm{~d}$ for BDL). RNA was isolated and cDNA was made using a commercial MMLV-RT kit. The cDNA samples were analyzed by quantitative RT-PCR using Fmo3 mouse-specific primers. Gene expression was normalized to the housekeeping gene $\beta$-actin. Fmo3 mRNA expression is presented as mean Fold Change \pm SE. One-way ANOVA, t-test or two-way ANOVA was performed, appropriately, followed by the Dunnett's posttest for One-way ANOVA and the Bonferroni posttest for two-way ANOVA. Asterisks (*) represent a statistical difference $(\mathrm{p}<0.05)$ between vehicle-treated and hepatotoxicant-treated or BDL group. 

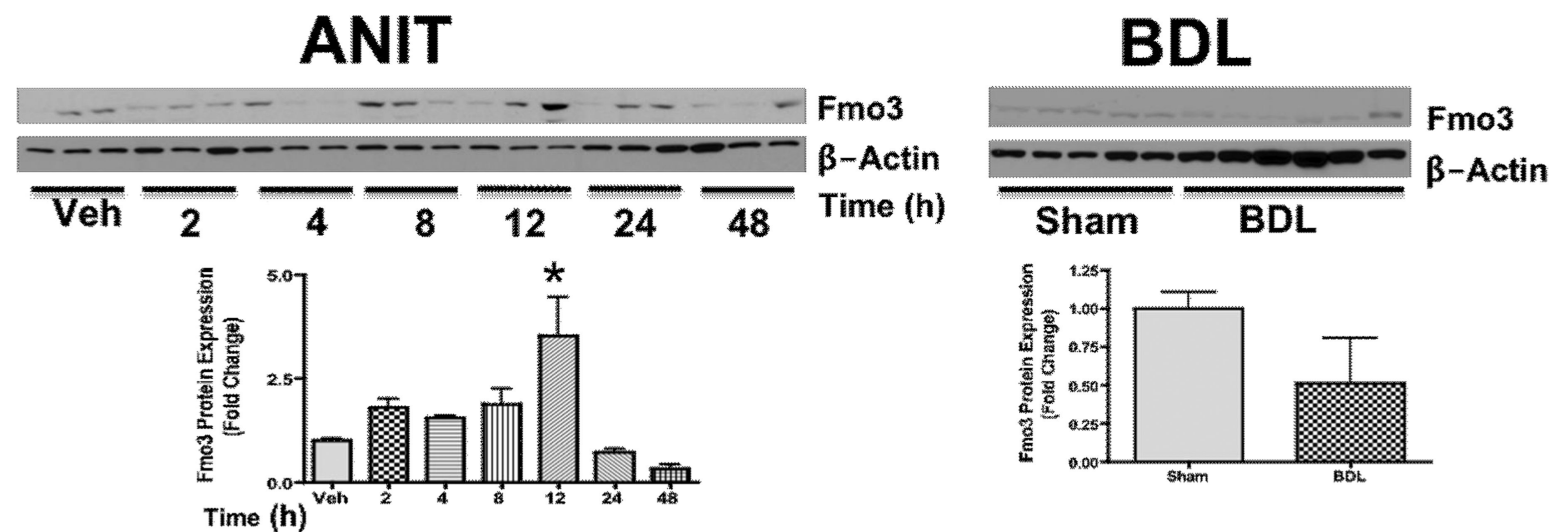

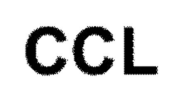

Timeppint: $24 \mathrm{~h}$

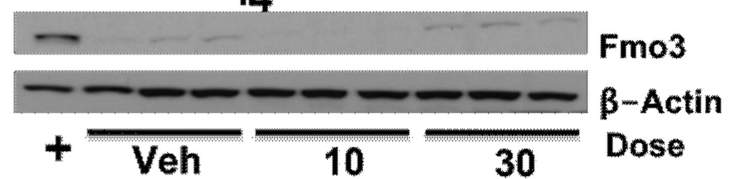

Timepoint: $\mathbf{4 8 ~ h}$
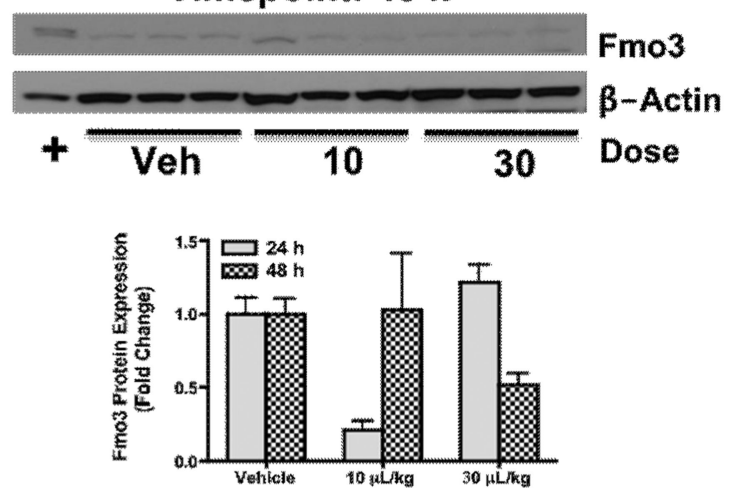

\section{$\mathrm{AlOH}$}

Timepoint: $6 \mathrm{~h}$

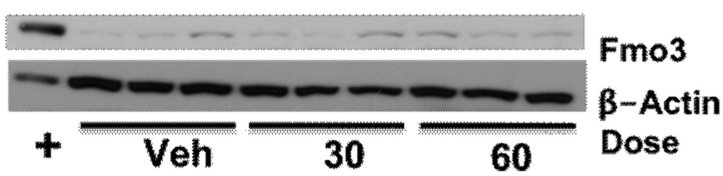

Timepoint: $24 \mathrm{~h}$

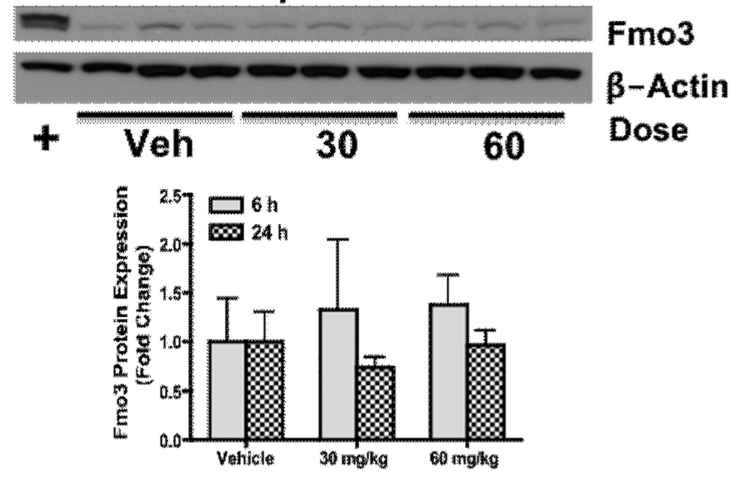

Figure 5. Analysis of liver Fmo3 protein expression in the mouse models of liver injury by western blotting

Western immunoblots for Fmo3 were performed using liver microsomes from control and hepatotoxicant-treated or BDL mice. A custom-made rabbit anti-mouse Fmo3 primary antibody, described in Materials and Methods was used to detect Fmo3. Fmo3 protein levels were normalized to $\beta$-actin loading control. Microsomal proteins isolated from naïve female mouse liver were used as a positive control (indicated by “+” sign). The data are presented as blots and as mean Fmo3 protein expression (Fold Change) \pm SE. One-way ANOVA, $t-$ test or two-way ANOVA was performed, appropriately, followed by the Dunnett's posttest for One-way ANOVA and the Bonferroni posttest for two-way ANOVA. Asterisks (*) represent a statistical difference $(\mathrm{p}<0.05)$ between vehicle-treated and hepatotoxicanttreated or BDL group. 

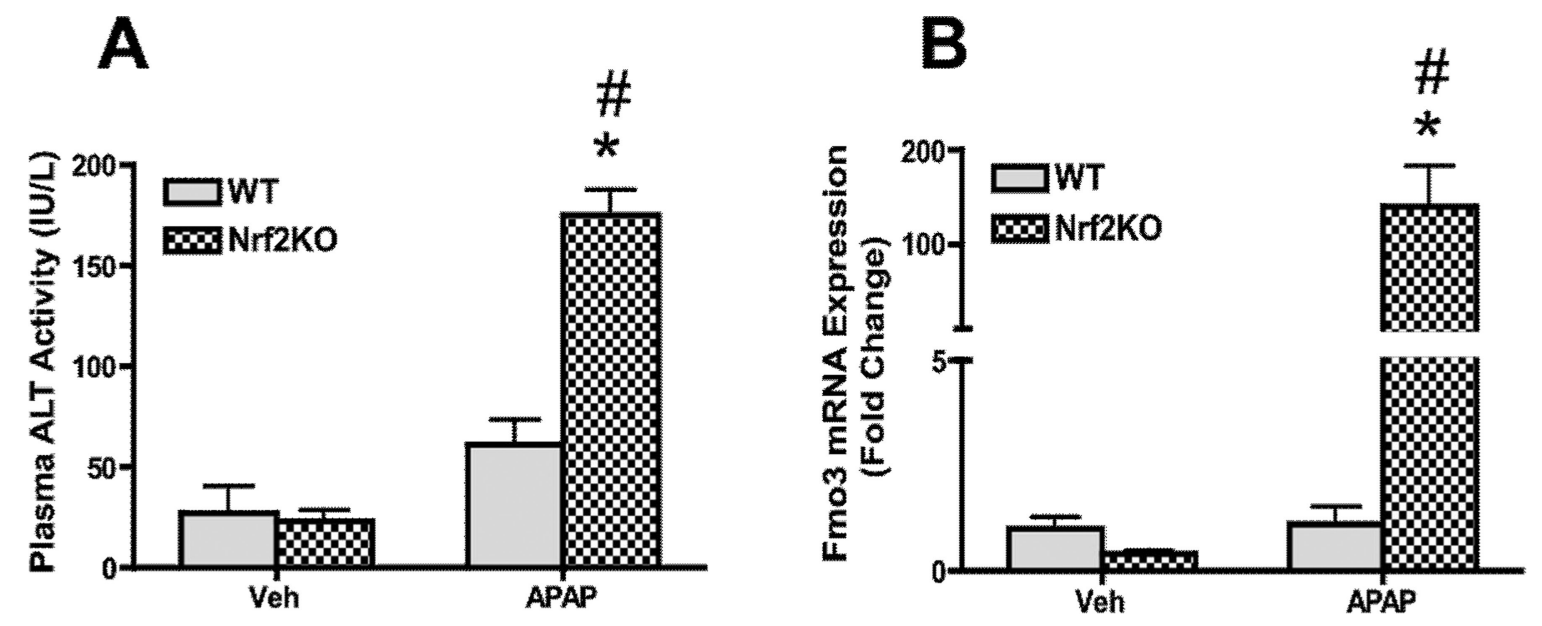

Figure 6. Plasma ALT activity and quantitative RT-PCR analysis of liver Fmo3 transcripts following a single dose APAP treatment in wild-type and Nrf2knockout mice

Plasma and livers were collected from mice $72 \mathrm{~h}$ following APAP (400 mg/kg) or vehicle treatment. (A) The data are presented as mean plasma ALT (IU/L) \pm SE. (B) RNA was isolated from livers andcDNA samples were analyzed by quantitative RT-PCR using Fmo3 mouse-specific primers. Gene expression was normalized to the housekeeping gene $\beta$-actin. Fmo3 mRNA expression are presented as mean Fold Change \pm SE. Oneway ANOVA was performed followed by the Dunnett's post-test. Asterisks (*) represent a statistical difference $(\mathrm{p}<0.05)$ between vehicle-treated group and APAP-treated group and hash (\#) represent a statistical difference $(\mathrm{p}<0.05)$ compared with APAP-treated wild-type mice. 


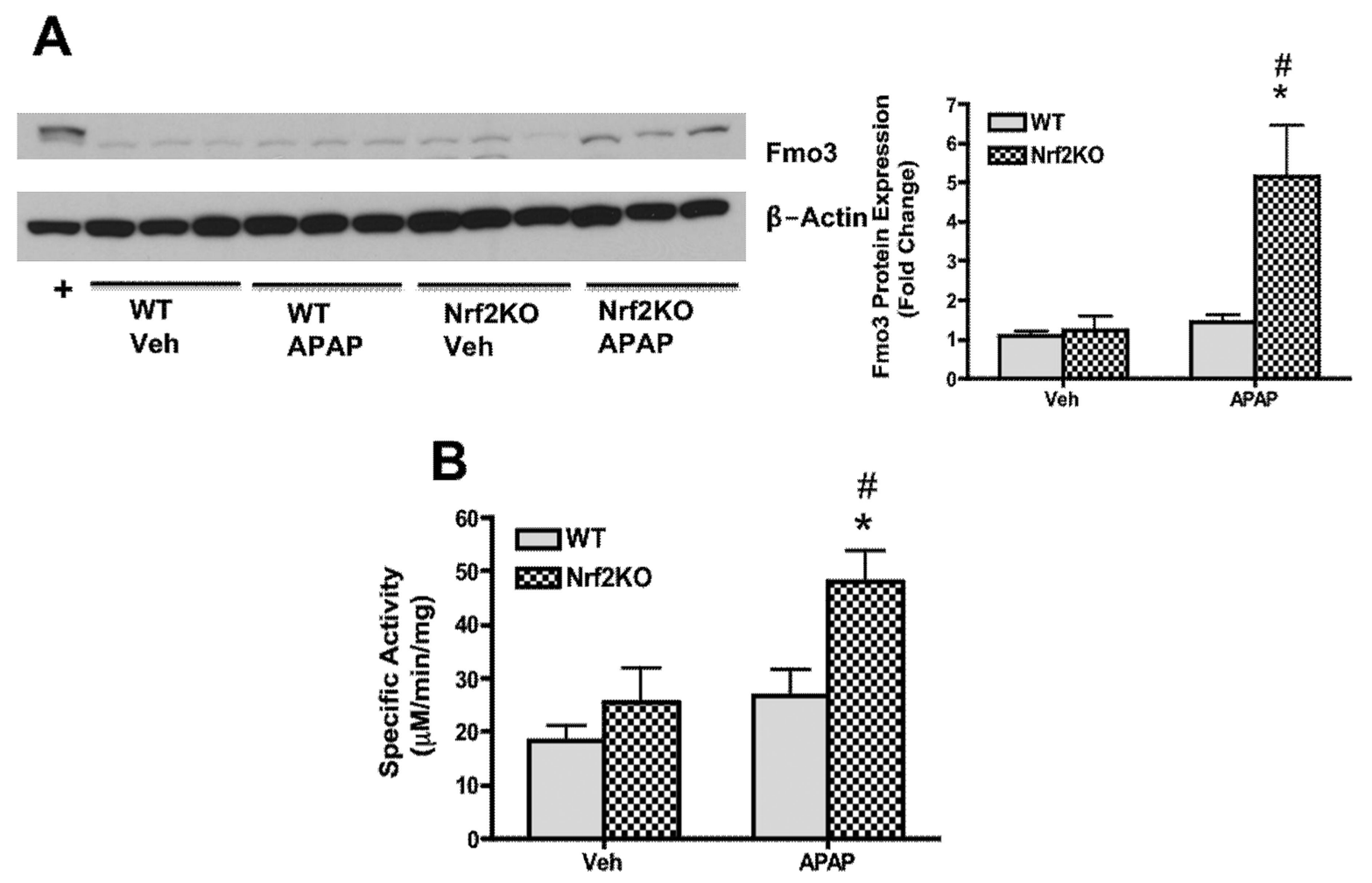

Figure 7. Analysis of liver Fmo3 protein expression following a single dose APAP treatment in wild-type and Nrf2knockout mice by western blotting and enzyme activity assay

After overnight fasting, groups of wild-type and Nrf2 knockout mice received a single dose of $400 \mathrm{mg} / \mathrm{kg}$ APAP or vehicle. Livers were collected $72 \mathrm{~h}$ following APAP or vehicle treatments. Western blot for Fmo3 was performed using liver microsomes from control and APAP-treated mice. Equal protein loading (10 $\mu$ g protein/lane) was confirmed by detection of $\beta$-actin. Microsomal proteins isolated from naïve female mouse liver were used as a positive control indicated by "+" sign. The data are presented as blots and as mean Fmo3 protein expression (Fold Change) \pm SE (A). FMO activity was measured in liver microsomes from control and APAP-treated mice using methimazole as substrate. Data are presented as mean Specific Activity $(\mu \mathrm{M} / \mathrm{min} / \mathrm{mg}) \pm \mathrm{SE}$ (B). Asterisks (*) represent a statistical difference $(\mathrm{p}<0.05)$ between vehicle-treated group and APAP-treated group and hash $(\#)$ represent a statistical difference $(\mathrm{p}<0.05)$ compared with APAP-treated wild-type mice. 